\title{
Efficiency improvement of pyrolysis
}

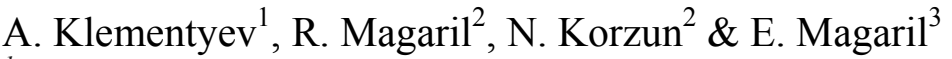 \\ I "Tobolsk-Polymer" LLC, Russia \\ ${ }^{2}$ Tyumen State Oil and Gas University, Russia \\ ${ }^{3}$ Ural Federal University, Russia
}

\begin{abstract}
Ethylene production by pyrolysis of hydrocarbon gases (ethane, propane, butane) and liquid fractions provides better selectivity to ethylene at higher temperatures, as has been well documented in studies. Temperature increase accelerates chainradical reactions of ethylene formation. Acceleration of chain-radical process can be achieved at a given temperature by the presence of an initiating agent of radical formation in the feedstock. Bimolecular reaction of allene (propadiene) with either alkane or alkene hydrocarbons and is an extremely rapid reaction of radicals formation because the endothermicity of this reaction is small and steric ratio is high. This paper considers the use of allene as the initiator of chainradical reactions of pyrolysis.
\end{abstract}

Keywords: pyrolysis, propadiene (allene), radical chain reactions.

\section{Introduction}

About $140 \mathrm{MM}$ tons of ethylene was produced worldwide in 2012 utilizing over $400 \mathrm{MM}$ tons of raw material. Improved ethylene selectivity is very important in view of the growing demand of monomers. This paper demonstrates that allene significantly increases the initiation rate of pyrolysis radical chain reactions and thereby increasing the yield of ethylene from feedstock. A process design, which requires recirculation of allene formed in the process, is proposed. 


\section{Influence of initiating step on the chain-radical reactions rate}

The radical-chain reaction rate is $W=k_{c} \cdot[\dot{\mathrm{R}}] \cdot[\mathrm{M}]$, where $k_{c}$ is kinetic constant of chain propagation, $[\dot{\mathrm{R}}]$ - radical concentration, and $[\mathrm{M}]$ - reacting hydrocarbons concentration. Radical concentration can be calculated by condition of equality of rates of initiation and destruction of radicals, $W_{i}=k_{r}$. $[\dot{\mathrm{R}}]^{2}$, where $W_{i}$ is the initiation rate and $k_{r}$ - the radicals recombination-rate constant. Therefore, radical concentration is $[\dot{\mathrm{R}}]=\sqrt{\frac{W_{i}}{k_{r}}}$. Thus, the pyrolysis radical-chain reaction rate is $W=k_{c} \cdot \sqrt{\frac{W_{i}}{k_{r}}} \cdot[M]$, so it is proportional with $W_{i}$.

The rate constant of allene reaction with alkanes is estimated by activation energy $(E)$ in the range from 113 to $182 \mathrm{~kJ}$ and a minimum steric factor $p$ of 0.1 [1]. The rate of radicals formation resulting in reactions $\mathrm{C}_{3} \mathrm{H}_{4}+\mathrm{C}_{3} \mathrm{H}_{6}$, $\mathrm{C}_{3} \mathrm{H}_{4}+\mathrm{C}_{3} \mathrm{H}_{8}$ are much faster than the chains initiated during unimolecular decomposition of propane and propylene having an activation energy $E$ in the range from 354 to $360 \mathrm{~kJ}$ [1-3]. This is explained by relatively low activation energies of bimolecular reactions.

Let us consider a low conversion pyrolysis reaction of propane (propylene concentration is $0.1 \mathrm{~mol} \%$ ). $1 \mathrm{~mol} \%$ of allene is injected in the raw material.

Chain initiation stage can be the following (1):

$$
\mathrm{C}_{3} H_{4}+\mathrm{C}_{3} H_{6}=2 \dot{C}_{3} H_{5}-113000 \mathrm{~J} / \mathrm{mole}
$$

Reaction (1) rate:

$$
W_{1}=k_{1} \cdot\left[C_{3} H_{4}\right] \cdot\left[C_{3} H_{6}\right]=10^{-11} \cdot e^{-\frac{113000}{R T}} \cdot 10^{17} \cdot 10^{16} \text { molecule } \cdot \mathrm{cm}^{-3} \cdot \mathrm{sec}^{-1} .
$$

Initiation can also take place according to reaction (2):

$$
\mathrm{C}_{3} H_{4}+\mathrm{C}_{3} H_{8}=\dot{C}_{3} H_{5}+\dot{C}_{3} H_{7}-181780 \mathrm{~J} / \mathrm{mole}
$$

Reaction (2) rate:

$$
W_{2}=k_{2} \cdot\left[C_{3} H_{4}\right] \cdot\left[C_{3} H_{8}\right]=10^{-11} \cdot e^{-\frac{181780}{R T}} \cdot 10^{17} \cdot 10^{19} \text { molecule } \cdot \mathrm{cm}^{-3} \cdot \mathrm{sec}^{-1} \text {. }
$$

The third option of initiation is propane unimolecular decomposition:

$$
\mathrm{C}_{3} H_{8}=\dot{C}_{2} H_{5}+\dot{C} H_{3}-354000 \mathrm{~J} / \text { mole }
$$


Reaction (3) rate:

$$
W_{3}=k_{3} \cdot\left[C_{3} H_{8}\right]=10^{15} \cdot e^{-\frac{354000}{R T}} \cdot 10^{19} \text { molecule } \cdot \mathrm{cm}^{-3} \cdot \mathrm{sec}^{-1} .
$$

Rates for initiating reactions (1)-(3), respectively (4)-(6):

$$
\begin{aligned}
& W_{1}=10^{22} \cdot e^{-\frac{113000}{R T}} \text { molecule } \cdot \mathrm{cm}^{-3} \cdot \mathrm{sec}^{-1} \\
& W_{2}=10^{25} \cdot e^{-\frac{181780}{R T}} \text { molecule } \cdot \mathrm{cm}^{-3} \cdot \mathrm{sec}^{-1} \\
& W_{3}=10^{34} \cdot e^{-\frac{354000}{R T}} \text { molecule } \cdot \mathrm{cm}^{-3} \cdot \mathrm{sec}^{-1} .
\end{aligned}
$$

Activation energies were determined from heat effects of reactions [1, 3].

Chain initiation rates for these reactions at different temperatures are shown in Table 1.

It is shown that at temperatures below $1000 \mathrm{~K}$ initiation in reactions with allene is much faster than the reaction of propane unimolecular decomposition. Reaction of allene and propylene proceeds with high speed even at very low concentrations of propylene.

Table 1: The rate of initiation by the reactions (1) $-(3)$, molecule $\cdot \mathrm{cm}^{-3} \cdot \mathrm{sec}^{-1}$.

\begin{tabular}{|c|c|c|c|}
\hline $\mathrm{T}, \mathrm{K}$ & $C_{3} H_{4}+\mathrm{C}_{3} H_{6}=2 \dot{C}_{3} H_{5}$ & $C_{3} H_{4}+C_{3} H_{8}=\dot{C}_{3} H_{5}+\dot{C}_{3} H_{7}$ & $C_{3} H_{8}=\dot{C}_{2} H_{5}+\dot{C} H_{3}$ \\
\hline 1110 & $10^{16.679}$ & $10^{16.400}$ & $10^{17.331}$ \\
\hline 1053 & $10^{16.384}$ & $10^{15.965}$ & $10^{16.405}$ \\
\hline 1000 & $10^{16.088}$ & $10^{15.489}$ & $10^{15.479}$ \\
\hline 900 & $10^{15.443}$ & $10^{14.452}$ & $10^{13.459}$ \\
\hline 833 & $10^{14.906}$ & $10^{13.587}$ & $10^{11.775}$ \\
\hline
\end{tabular}

Allene is produced during pyrolysis at the highest temperatures in the following reaction: $\mathrm{C}_{3} \mathrm{H}_{6} \rightarrow \dot{\mathrm{C}}_{3} \mathrm{H}_{5}+\dot{H} \rightarrow \mathrm{C}_{3} \mathrm{H}_{4}+\dot{H}$.

Allene formation can proceed only at high temperatures, when allene evinces no initiating ability and has no influence on the process, due to the high endothermicity of the allyl radical's dissociation.

\section{Experimental study of allene effect on pyrolysis process}

Recirculation of allene formed during pyrolysis can improve process efficiency. When allene is injected into pyrolysis feedstock, the product balance changes due to the initiating action of allene. The authors carried out petrol pyrolysis with and without the addition of allene. The results are shown in Tables $2-4$. 
As seen from the tables below, the yield of ethylene was raised by up to a relative $10 \%$ due to the initiating effect of allene. Yield of the target gaseous products of pyrolysis is accompanied by a reduction of liquid products yield.

Table 2: $\quad$ Results of naphtha pyrolysis (fraction $85-150^{\circ} \mathrm{C}$ ), feedstock to inert diluent (helium) ratio is $1: 3.66 \mathrm{~mole} / \mathrm{mole}$.

\begin{tabular}{|c|c|c|}
\hline \multirow{2}{*}{ Pyrolysis products } & Pyrolysis products yield, \% wt per raw material \\
\cline { 2 - 3 } & $\begin{array}{c}\text { w/o allene, pyrolysis } \\
\text { time } 0.5 \mathrm{sec}\end{array}$ & $\begin{array}{c}0.3 \% \text { wt of allene, } \\
\text { pyrolysis time } 0.05 \mathrm{sec}\end{array}$ \\
\hline \multicolumn{3}{|c|}{ Temperature $820^{\circ} \mathrm{C}$} \\
\hline $\mathrm{C}_{2} \mathrm{H}_{4}$ & 33.0 & 35.5 \\
\hline $\mathrm{C}_{3} \mathrm{H}_{6}$ & 15.0 & 16.4 \\
\hline $\mathrm{C}_{4} \mathrm{H}_{6}$ & 5.0 & 9.0 \\
\hline \multicolumn{3}{|c|}{ Temperature $790^{\circ} \mathrm{C}$} \\
\hline $\mathrm{C}_{2} \mathrm{H}_{4}$ & 27.0 & 29.5 \\
\hline $\mathrm{C}_{3} \mathrm{H}_{6}$ & 15.0 & 16.4 \\
\hline $\mathrm{C}_{4} \mathrm{H}_{6}$ & 6.0 & 10.0 \\
\hline
\end{tabular}

Table 3: Outputs of main products for pyrolysis of fractions $70-100^{\circ} \mathrm{C}$ of gasoline raffinate, at $820^{\circ} \mathrm{C}, 0.1 \mathrm{MPa}$, pyrolysis time $1 \mathrm{sec}$, ratio of raw material to inert diluent (helium) is 1: $3.66 \mathrm{~mole} / \mathrm{mole}$.

\begin{tabular}{|c|c|c|c|}
\hline \multirow{2}{*}{$\begin{array}{c}\text { Allene added, } \\
\text { \% wt per raw } \\
\text { material }\end{array}$} & \multicolumn{3}{|c|}{ Output, \% wt per raw material } \\
\cline { 2 - 4 } & $\mathrm{C}_{2} \mathrm{H}_{4}$ & $\mathrm{C}_{3} \mathrm{H}_{6}$ & $\mathrm{C}_{5+}$ \\
\hline 0.0 & $24.7 \pm 0.7$ & $12.3 \pm 0.2$ & $22.3 \pm 0.6$ \\
\hline 0.3 & $27.3 \pm 0.2$ & $13.2 \pm 0.7$ & $19.1 \pm 0.6$ \\
\hline 0.5 & $27.8 \pm 0.3$ & $13.6 \pm 0.6$ & $17.3 \pm 0.5$ \\
\hline
\end{tabular}

Table 4: $\quad$ Allene influence on pyrolysis of gasoline fraction $70-140^{\circ} \mathrm{C}$ with helium as diluent in the ratio $1: 3$ mole/mole of raw material.

\begin{tabular}{|c|c|c|c|c|c|c|}
\hline \multirow{2}{*}{$\begin{array}{c}\text { Temperature, } \\
{ }^{\circ} \mathrm{C}\end{array}$} & \multirow{2}{*}{$\begin{array}{c}\text { Pyrolysis } \\
\text { time, sec }\end{array}$} & \multirow{2}{*}{$\begin{array}{c}\text { Allene } \\
\text { adding, } \\
\% \mathrm{wt}\end{array}$} & \multicolumn{4}{|c|}{ Output, \% wt per raw material } \\
\cline { 4 - 8 } & $\mathrm{C}_{2} \mathrm{H}_{4}$ & $\mathrm{C}_{3} \mathrm{H}_{6}$ & $\mathrm{C}_{4} \mathrm{H}_{6}$ & $\mathrm{C}_{5+}$ \\
\hline 835 & 0.5 & 0.0 & 32.9 & 20.5 & 4.3 & 9.5 \\
\hline 835 & 0.5 & 1.0 & 35.3 & 21.4 & 5.8 & 8.8 \\
\hline 800 & 1.0 & 0.0 & 30.5 & 19.9 & 3.7 & 18.8 \\
\hline 800 & 1.0 & 1.0 & 32.5 & 21.7 & 4.4 & 14.8 \\
\hline
\end{tabular}

Fig. 1 shows the proposed by authors process flow diagram of pyrolysis. 


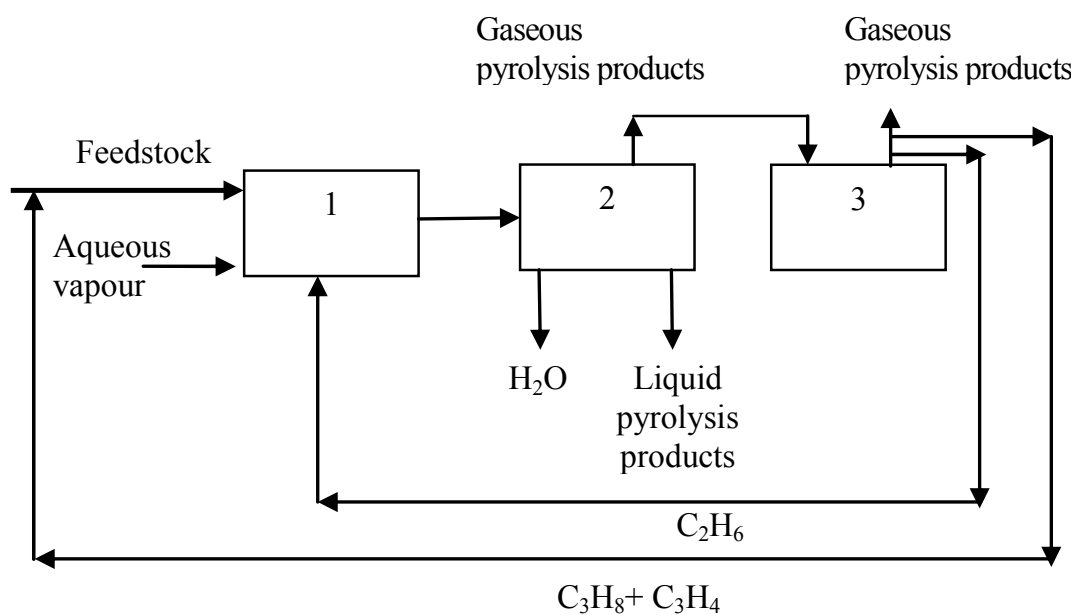

Figure 1: $\quad$ Pyrolysis flow chart: 1 - pyrolysis furnaces section; 2 - recovery of liquid products; 3 - unit of gaseous products' rectification.

The resulting allene is entirely recycled as part of a mixture with propane, which is injected into the feedstock.

\section{Conclusion}

Recirculation of allene will improve ethylene yield by up to a relative $10 \%$ by means of the initiating action of allene and in addition by pyrolysis of propane. Furthermore, recirculation of propane increases ethylene yield.

The yield of liquid products of condensation decreases, apparently due to the fact that its formation occurs partly by molecular mechanism. Allene accelerates the radical chain reaction of pyrolysis while condensation molecular reactions remain non-accelerated. Allene may be separated in the residue of propane/propylene splitter column and arrangements for its recirculation do not require substantial capital expenses.

\section{References}

[1] Magaril, R.Z., Theoretical foundations of chemical refining processes: monograph, [in Russian], KDU: Moscow, 2010.

[2] Korzun, N.V., Magaril, R.Z., Thermal processes of refining, [in Russian], KDU: Moscow, 2008.

[3] Gurvich, L.V., Karachevcev, G.V., Kondratyev, V.N. et al., Bond opening energies. The ionization potentials and electron affinities, [in Russian], Nauka: Moscow, 1974. 